\title{
Characterization of Full-Length and Truncated Recombinant $\kappa$-Carrageenase Expressed in Pichia pastoris
}

\author{
Yuan Yu, Zhemin Liu, Min Yang, Meng Chen, Zhihan Wei, Lixia Shi, Li Li* and Haijin Mou* \\ College of Food Science and Engineering, Ocean University of China, Qingdao, China
}

OPEN ACCESS

Edited by:

Regina-Michaela Wittich,

Estación Experimental del Zaidín

(CSIC), Spain

Reviewed by:

Luciano Takeshi Kishi,

Univ Estadual Paulista UNESP/FCAV,

Brazil

Jose M. Bruno-Barcena,

North Carolina State University,

United States

Ana Paulina Barba De La Rosa,

Institute for Scientific and

Technological Research, Mexico

*Correspondence:

Haijin Mou

mousun@ouc.edu.cn

$\mathrm{Li} \mathrm{Li}$

IIcs0229@163.com

Specialty section:

This article was submitted to Microbiotechnology, Ecotoxicology and Bioremediation,

a section of the journal

Frontiers in Microbiology

Received: 16 May 2017

Accepted: 31 July 2017

Published: 15 August 2017

Citation:

Yu Y, Liu Z, Yang M, Chen M, Wei Z,

Shi L, Li L and Mou H (2017)

Characterization of Full-Length

and Truncated Recombinant

$\kappa$-Carrageenase Expressed in Pichia pastoris. Front. Microbiol. 8:1544. doi: 10.3389/fmicb.2017.01544
$\kappa$-Carrageenase belongs to glycoside hydrolase family 16 and cleaves the $\beta$ - $(1 \rightarrow 4)$ linkages of $\kappa$-carrageenan. In this study, genes encoding the full-length (cgkZ), Por secretion tail-truncated (cgkZ $\Delta P s t)$ and carbohydrate binding domain-truncated $(c g k Z \triangle C B M) \kappa$-carrageenase proteins were expressed in Pichia pastoris. The copy numbers of gene $c g k Z, c g k Z \Delta P s t$ and $c g k Z \Delta C B M$ were 7,7 and 6 , respectively. The enzymatic activities of recombinant enzymes cgkZ, cgkZ $\Delta$ Pst and cgkZ $\Delta C B M$ reached $4.68,5.70$, and $3.02 \mathrm{U} / \mathrm{mL}$, respectively, after $120 \mathrm{~h}$ of shake flask fermentation at $22^{\circ} \mathrm{C}$ and $\mathrm{pH} 6$ in the presence of $1 \%(\mathrm{v} / \mathrm{v})$ methanol. The molecular weights of recombinant cgkZ, cgkZ $\Delta$ Pst, and $c g k Z \Delta C B M$ were approximately 65,45 , and $40 \mathrm{kDa}$; their $\mathrm{K}_{\mathrm{m}}$ values were 2.07, 1.85, and $1.04 \mathrm{mg} / \mathrm{mL}$; and they exhibited optimal activity at $45-50^{\circ} \mathrm{C}$ and $\mathrm{pH} 6-7$. All the recombinant enzymes were stimulated by $\mathrm{Na}^{+}, \mathrm{Mg}^{2+}, \mathrm{Ca}^{2+}$, and dithiothreitol. The end-products of enzymatic hydrolysis were mainly composed of $\kappa$-carrageenan tetrasaccharide and hexasaccharide. The removal of the Por secretion tail of $\kappa$-carrageenase promoted the transcription of $\kappa$-carrageenase gene, enhancing the specific activity of $\kappa$-carrageenase without significantly changing its catalytic properties. Although the transcription level of $\kappa$-carrageenase gene after the removal of the carbohydrate binding domain was relatively high, the specific activity of the recombinant enzyme significantly decreased. The comprehensive application of the $P$. pastoris expression system combined with the rational modification of genes may provide a novel approach for the heterologous expression of various marine enzymes with high activities.

Keywords: $\kappa$-carrageenase, Pichia pastoris expression system, gene truncation, heterologous expression, enzymatic characterization

\section{INTRODUCTION}

$\kappa$-Carrageenan is an important raw material in the food industry, and it is mainly used as a stabilizer and gelling agent (Mora-Gutierrez et al., 1998). $\kappa$-Carrageenan is a linear sulfated polysaccharide with a repeating unit composed of $\alpha-(1 \rightarrow 3)$-4-sulfated galactose $\left(\mathrm{G}_{4 \mathrm{~S}}\right)$ and $\beta$-(1 $\rightarrow 4)-(3,6)$ anhydrogalactose (A) (Hargreaves et al., 2013). Its degradation products, 
$\kappa$-carrageenan oligosaccharides, have anti-oxidant, anti-viral, anti-tumor and anti-inflammatory activities (Raman and Doble, 2015; Yu et al., 2017). Acid hydrolysis and enzymatic hydrolysis methods are typically used to prepare $\kappa$-carrageenan oligosaccharides. Compared with acid hydrolysis methods, the enzymatic method catalyzes the hydrolysis of specific glycosidic linkages on polysaccharides, and the degree of polymerization can be controlled by adjusting the hydrolysis conditions. Thus, enzymatic hydrolysis can prevent damage to the polysaccharide structure (Zhu et al., 2016; Zhang et al., 2016). Enzymatic hydrolysis is considered a mild, environmentally friendly, and sustainable method for preparing $\kappa$-carrageenan oligosaccharides.

$\kappa$-Carrageenase (EC 3.2.1.83) specifically cleaves the $\beta$ - $(1 \rightarrow 4)$ linkages of $\kappa$-carrageenan, which belongs to glycoside hydrolase family 16 (Mou et al., 2003). Many types of bacterial genera secrete $\kappa$-carrageenase, mainly including Alteromonas, Cytophaga, Pseudoalteromonas, Pseudomonas, and Zobellia (Liu et al., 2011). The structure of $\kappa$-carrageenase from Pseudoalteromonas carrageenovora was previously described by $\mathrm{X}$-ray diffraction experiments. $\kappa$-Carrageenase molecules are mainly composed of $\beta$ sheets and random coils, with each $\beta$ sheet containing 6-7 $\beta$ chains arranged in a "tunnel-like" three-dimensional structure. The reverse stacking of $\beta$ sheets contributes to the formation of "tunnel-like" catalytic sites (Michel et al., 2001).

The optimum temperature and $\mathrm{pH}$ for the activity of $\kappa$-carrageenase produced by Zobellia sp. ZM-2 (cgkZ) are $39^{\circ} \mathrm{C}$ and 6.0, respectively. This enzyme contains 12 active sites and 3 catalytic sites. The amino acid sequence of the catalytic region is E-I-D-V-V-E (Liu et al., 2013). The full-length gene encoding cgkZ is 1638 base pairs (bp) long, and the encoded protein consists of 545 amino acids (aa). The functional site of cgkZ includes the following regions (Figure 1A): signal peptide (1-29 aa), $\mathrm{CH}-16 \kappa$-carrageenase catalytic domain (35-315 aa), carbohydrate binding domain (CBM, 320-399 aa), and C-terminal Por secretion tail (Pst, 470-545 aa) (NCBI). ${ }^{1}$ Liu et al. (2013) expressed the cgkZ gene in Escherichia coli, and found the total enzymatic activity of $\kappa$-carrageenase to be $2.98 \mathrm{U} / \mathrm{mL}$.

Pichia pastoris is a eukaryotic microorganism which is suitable for high-density fermentation. Various heterologous proteins from bacteria, fungi, plants, animals, and humans have been successfully expressed in P. pastoris (Cereghino and Cregg, 2000; Macauley-Patrick et al., 2005; Haon et al., 2015). $P$. pastoris can perform various eukaryotic post-translational modifications including the formation of disulfide bonds and glycosylation, which can be essential for the structural stability and enzymatic activity of recombinant proteins (Haon et al., 2015; Zhang et al., 2015). In this study, the genes encoding the full-length ( $c g k Z)$ and truncated (cgkZ $\Delta P s t$ and $c g k Z \triangle C B M) \kappa$-carrageenase proteins were expressed in $P$. pastoris to optimize the expression of recombinant $\kappa$-carrageenase and obtain recombinant $\kappa$-carrageenase having a high activity.

\footnotetext{
${ }^{1}$ https://blast.ncbi.nlm.nih.gov/Blast.cgi
}

\section{MATERIALS AND METHODS}

\section{Strains, Plasmids and Media}

Zobellia sp. ZM-2 strain (CCTCC No. M2013256) is now preserved in the China Center for Type Culture Collection (Wuhan, China). P. pastoris GS-115 ( $\mathrm{Mut}^{+}$) strain and plasmid pPIC9K were purchased from Invitrogen (Carlsbad, CA, United States). Luria-Bertani medium (LB) contained $5 \mathrm{~g} / \mathrm{L}$ yeast extract, $10 \mathrm{~g} / \mathrm{L}$ peptone, $10 \mathrm{~g} / \mathrm{L} \mathrm{NaCl}$, and $100 \mu \mathrm{g} / \mathrm{mL}$ ampicillin (20 g/L agar was added for preparing solid medium). Minimal dextrose medium (MD) contained $13.4 \mathrm{~g} / \mathrm{L}$ yeast nitrogen base (YNB) without amino acids (Solarbio, Beijing, China), 20 g/L glucose, $0.4 \mathrm{mg} / \mathrm{L}$ biotin, and $20 \mathrm{~g} / \mathrm{L}$ agar. Yeast extract peptone dextrose medium (YPD) contained $10 \mathrm{~g} / \mathrm{L}$ yeast extract, $20 \mathrm{~g} / \mathrm{L}$ peptone, and $20 \mathrm{~g} / \mathrm{L}$ glucose $(20 \mathrm{~g} / \mathrm{L}$ agar was added for preparing solid medium). Buffered minimal glycerol medium (BMGY) contained $10 \mathrm{~g} / \mathrm{L}$ yeast extract, $20 \mathrm{~g} / \mathrm{L}$ peptone, $10 \mathrm{~g} / \mathrm{L}$ glycerol, $3 \mathrm{~g} / \mathrm{L} \mathrm{K}_{2} \mathrm{HPO}_{4}$, and $11.8 \mathrm{~g} / \mathrm{L} \mathrm{KH}_{2} \mathrm{HPO}_{4}$.

\section{Gene Cloning and Recombinant Vector Construction}

The complete $\kappa$-carrageenase gene ( $c g k Z)$ sequence was obtained from the NCBI GenBank database (accession No. KC503903). Three pairs of primers were used to amplify the genes $c g k Z$, cgkZ $\triangle$ Pst and cgkZ $\triangle C B M$ (Table 1). PCR was performed using Zobellia sp. ZM-2 genomic DNA as a template and high-fidelity $P f u$ DNA polymerase (Takara, Shiga, Japan). After the purification of the PCR products, the target genes and the vector pPIC9K were digested with AvrII and NotI (Thermo Fisher Scientific, Waltham, MA, United States). The digested products were purified by gel recycling, and the target gene and vector were ligated using T4 DNA ligase (Thermo Fisher Scientific, Waltham, MA, United States). The ligated product was transformed into $\mathrm{DH} 5 \alpha$ competent cells. Selected positive colonies were cultured in LB medium containing $100 \mu \mathrm{g} / \mathrm{mL}$ ampicillin at $37^{\circ} \mathrm{C}$ for $12 \mathrm{~h}$. The recombinant plasmids were extracted using a plasmid extraction kit (Omega, Winooski, VT, United States), and the plasmid sequences were determined by Sangon Biotech (Shanghai, China).

\section{Electroporation and Recombinant Strain Screening}

The recombinant plasmids pPIC9K-cgkZ, pPIC9K-cgkZ $\Delta$ Pst and pPIC9K-cgkZ $\triangle C B M$ were linearized using SalI and transformed into $P$. pastoris by electroporation using a MicroPulser ${ }^{\mathrm{TM}}$ electroporator (Bio-Rad, Hercules, CA, United States) at a voltage of $2 \mathrm{kV}$. After electroporation, the yeast cells were cultured in $\mathrm{MD}$ medium at $30^{\circ} \mathrm{C}$ for 3 days. Then the yeast cells were further diluted with sterile water and cultured on a YPD agar plate containing $4 \mathrm{mg} / \mathrm{mL}$ of geneticin (G418) at $30^{\circ} \mathrm{C}$ for another 3 days. The obtained colonies were activated in $10 \mathrm{~mL}$ of YPD medium at $28^{\circ} \mathrm{C}$ for $24 \mathrm{~h}$, and then $2 \mathrm{~mL}$ of medium was transferred to a $1 \mathrm{~L}$ shaker flask containing $200 \mathrm{~mL}$ BMGY medium. P. pastoris was cultured at $28^{\circ} \mathrm{C}$ for $72 \mathrm{~h}$ with the addition of methanol 


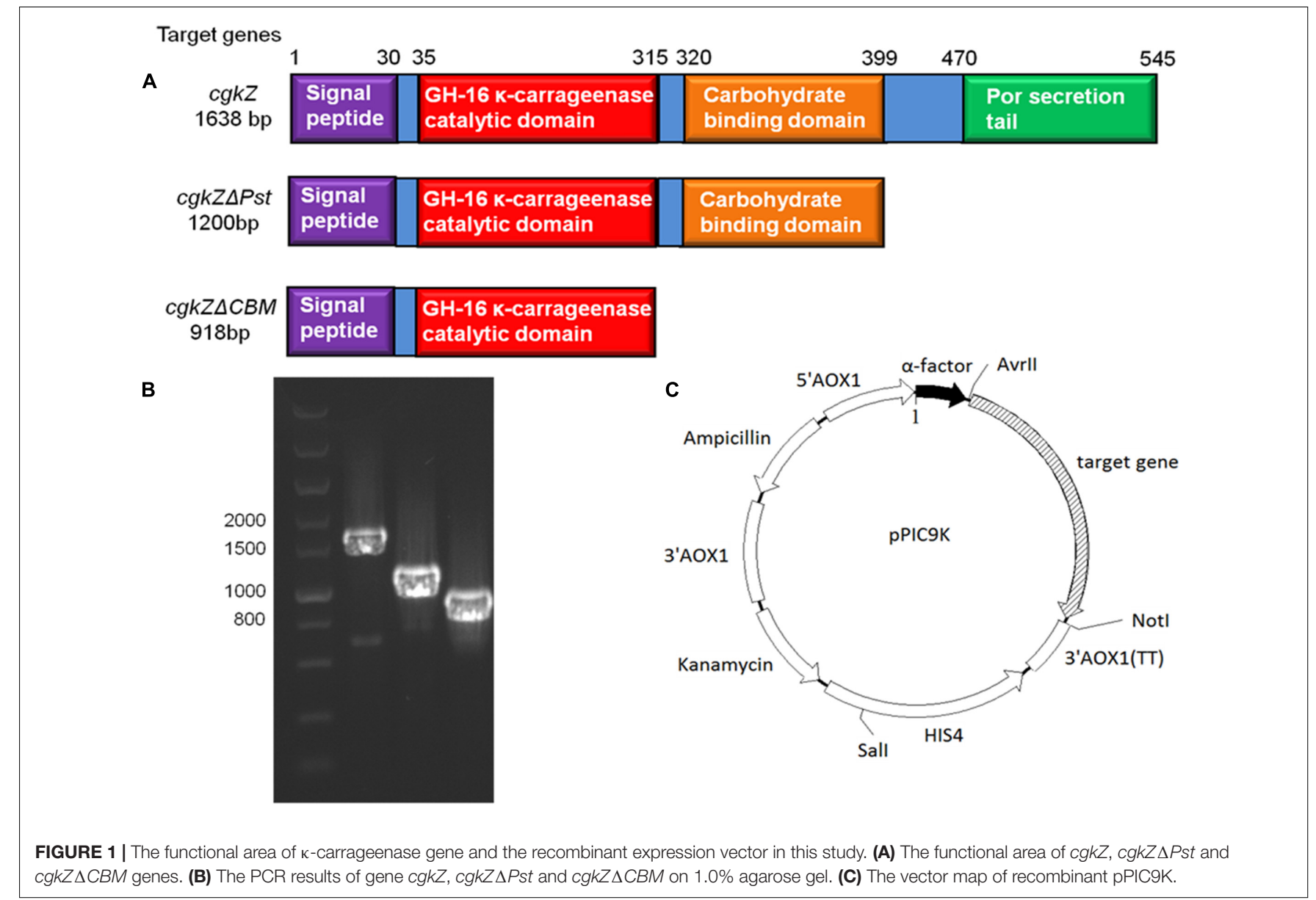

$(1 \%, \mathrm{v} / \mathrm{v})$ every $24 \mathrm{~h}$. After incubation, the culture was centrifuged and the supernatant was retained to measure $\kappa$-carrageenase activity. Enzymatic activity was measured as described by Liu et al. (2013) and protein concentration was measured using the Bradford method (Liu et al., 2011). Strains exhibiting high enzymatic activity were screened and stored at $-80^{\circ} \mathrm{C}$.

\section{Determination of Gene Copy Number}

The genomic DNA of $P$. pastoris was extracted using a Yeast DNA Kit (Omega, Winooski, VT, United States). The copy number of each target gene was determined by real-time quantitative PCR using a 7900 HT real-time PCR system (Applied Biosystems, Foster City, CA, United States). A 10 -fold series $\left(10^{3}-10^{8}\right.$ copies) of linearized plasmids containing $c g k Z$ and the endogenous gene (Glyceraldehyde 3-phosphate dehydrogenase, GAPDH), were used as templates to establish standard curves. The primers used in qPCR are listed in Table 1. PCR reactions were performed in a $20 \mu \mathrm{L}$ mixture containing $10 \mu \mathrm{L}$ of $2 \times$ Thunderbird SYBR qPCR Mix (Toyobo, Osaka, Japan), $0.3 \mu \mathrm{M}$ of each primer, and 50 ng of DNA template. The PCR parameters were $95^{\circ} \mathrm{C}$ for $60 \mathrm{~s}$, followed by $40 \mathrm{cycles}$ at $95^{\circ} \mathrm{C}$ for $15 \mathrm{~s}, 58^{\circ} \mathrm{C}$ for $30 \mathrm{~s}$, and $72^{\circ} \mathrm{C}$ for $60 \mathrm{~s}$. Melting curve analysis was used to determine the specificity of amplification. For each target gene, the copy numbers was calculated based on the ratio of gene copies between target gene and endogenous control.

\section{Optimization of Recombinant $\kappa$-Carrageenase Expression Conditions}

Fermentation conditions were optimized by modulating the temperature, $\mathrm{pH}$, and methanol concentration. The optimum fermentation temperature was determined by testing several temperatures $\left(22,24,26\right.$, and $\left.28^{\circ} \mathrm{C}\right)$. The optimum $\mathrm{pH}$ was determined in media containing $20 \mathrm{mM}$ of potassium phosphate at $\mathrm{pH} 5,6,7$, or 8 . Several concentrations of methanol $(0,0.5$, $1,1.5$, and $2 \% \mathrm{v} / \mathrm{v}$ ) were evaluated to determine the optimum concentration. The recombinant enzymes were obtained by fermentation under the optimal conditions for $120 \mathrm{~h}$ in a $1-\mathrm{L}$ shaker flask containing $200 \mathrm{~mL}$ of BMGY medium. Methanol $(1 \%, \mathrm{v} / \mathrm{v})$ was added into the fermentation culture every $24 \mathrm{~h}$. The enzymatic activity was measured every $12 \mathrm{~h}$.

\section{Determination of Transcription Levels}

After incubation in shaker flask for 36 and $72 \mathrm{~h}, 1 \mathrm{~mL}$ of fermentation broth was used for the determination of transcription levels. Total RNA was extracted using a Yeast RNA Kit (Omega, Winooski, VT, United States). RNA was diluted with $50 \mu \mathrm{L}$ of DEPC water and used for reverse transcription with 
TABLE 1 | Primers used in this study.

\begin{tabular}{|c|c|c|}
\hline Primer name & Primer sequences $\left(5^{\prime} \rightarrow 3^{\prime}\right)$ & Restriction sites \\
\hline FcgkZ & $\begin{array}{l}\text { CCGCCTAGGATGACAAAACTAAA } \\
\text { GTITAACGGC }\end{array}$ & Avr II \\
\hline $\operatorname{Rcgk} Z$ & $\begin{array}{l}\text { ATAAGAATGCGGCCGCTTACTCC } \\
\text { ACAAGTATCTT }\end{array}$ & Not I \\
\hline $\operatorname{Rcgk} Z \Delta P s t$ & $\begin{array}{l}\text { ATAAGAATGCGGCCGCTTAAGCC } \\
\text { GAAGTTCCGGGCG }\end{array}$ & Not I \\
\hline $\operatorname{Rcgk} Z \triangle C B M$ & $\begin{array}{l}\text { ATAAGAATGCGGCCGCTTATTCC } \\
\text { CATACCCGAACGTAAT }\end{array}$ & Not I \\
\hline FGAPDH-qPCR & $\begin{array}{l}\text { GGTATTAACGGTाTC } \\
\text { GGACGTATTG }\end{array}$ & \\
\hline RGAPDH-qPCR & $\begin{array}{l}\text { GATGTTGACAGGGT } \\
\text { СTCTCTCTTGG }\end{array}$ & \\
\hline FcgkZ-qPCR & $\begin{array}{l}\text { TCCGTAGCCAATG } \\
\text { GGGAAAC }\end{array}$ & \\
\hline RcgkZ-qPCR & $\begin{array}{l}\text { GGTCTTCTCCA } \\
\text { AACCCCCTG }\end{array}$ & \\
\hline
\end{tabular}

The underlined sequences represent restriction sites. FcgkZ and RcgkZ were used to amplify cgkZ. FcgkZ and RcgkZ $\Delta$ Pst were used to amplify cgkZ $\Delta$ Pst. FcgkZ and RcgkZ $\triangle C B M$ were used to amplify cgkZ $\triangle C B M$. Primer FGAPDH-qPCR, RGAPDH-qPCR, FcgkZ-qPCR and RcgkZ-qPCR were used to amplify GAPDH gene and target genes, respectively, in real-time qPCR.

ReverTra RT Master Mix (Toyobo, Osaka, Japan). The cDNA (25 ng) was used as a template to determine transcription levels by qPCR. Each qPCR reaction was performed as described above, with three biological replicates. The transcription level of each target gene was calculated based on the ratio of transcription levels between target mRNA and endogenous control (GAPDH).

\section{Purification of Recombinant $\kappa$-Carrageenase}

The fermentation broth was centrifuged at $4000 \times g$ for $20 \mathrm{~min}$ and the supernatant was concentrated by ultrafiltration using a $10 \mathrm{kDa}$ membrane. Recombinant enzymes were purified by cation exchange chromatography using a CM-Sepharose Fast flow column $(20 \mathrm{~cm} \times 1.6 \mathrm{~cm}$; GE Healthcare, Little Chalfont, United Kingdom), eluted first with $20 \mathrm{mM}$ phosphate buffer $(\mathrm{pH}$ 6.5) for an elution volume of $30 \mathrm{~mL}$, and then eluted with $20 \mathrm{mM}$ phosphate buffer ( $\mathrm{pH} 6.5$ ) containing $1 \mathrm{M} \mathrm{NaCl}$ for an additional elution volume of $30 \mathrm{~mL}$. Enzymatic activity and protein concentration were determined in samples obtained during purification. SDS-PAGE electrophoresis on a $12 \%(\mathrm{v} / \mathrm{v})$ gel was performed to determine the molecular weights of recombinant enzymes after purification, according to the method described by Liu et al. (2011).

\section{Enzymatic Characterization of Recombinant $\kappa$-Carrageenase}

The optimum temperature for the purified enzymes was determined by measuring their activity at $\mathrm{pH} 6$ and temperatures ranging from 30 to $65^{\circ} \mathrm{C}$. Thermal stability was determined as the residual activity after pre-incubating the enzymes for $0-4 \mathrm{~h}$ at several temperatures $\left(40,42.5,45,47.5\right.$, or $\left.50^{\circ} \mathrm{C}\right)$. The activity of the enzymes pre-incubated at $4^{\circ} \mathrm{C}$ was regarded as $100 \%$. The optimum $\mathrm{pH}$ for each purified enzyme was determined by measuring the enzymatic activity at $50^{\circ} \mathrm{C}$ in $20 \mathrm{mM}$ phosphate buffer with a $\mathrm{pH}$ ranging from 4 to 10 . To determine the effects of ions and chemical reagents, enzymatic activity was measured in solutions containing $5 \mathrm{mM}$ of $\mathrm{Cu}^{2+}, \mathrm{Ca}^{2+}, \mathrm{Zn}^{2+}, \mathrm{Mg}^{2+}, \mathrm{Fe}^{2+}$, $\mathrm{Fe}^{3+}$, EDTA, SDS, dithiothreitol (DTT); 10, 50, and $100 \mathrm{mM}$ of $\mathrm{Na}^{+}, \mathrm{K}^{+} ; 0.5 \%$ (v/v) of TritonX-100, Tween-80, methanol, and glycerol, respectively. Enzymatic activity was measured at $50^{\circ} \mathrm{C}$ and $\mathrm{pH}$ 6.0. The kinetic parameters of the purified enzymes were determined in solutions containing $\kappa$-carrageenan at concentrations between 1 and $10 \mathrm{mg} / \mathrm{mL}$ at $50^{\circ} \mathrm{C}, \mathrm{pH} 6.0$ for $5 \mathrm{~min}$. The Michaelis constant $\left(\mathrm{K}_{\mathrm{m}}\right)$ and $\mathrm{V}_{\max }$ were determined from Lineweaver-Burk double reciprocal plots using Origin Pro 8.0 (OriginLab, Northampton, MA, United States).

\section{Analysis of Hydrolysis Products of the Recombinant Enzymes}

Oligosaccharides were prepared by the enzymatic hydrolysis of $10 \mathrm{mg} / \mathrm{mL} \kappa$-carrageenan solution. Hydrolysis was performed in the presence of $1 \mathrm{~mL}$ of recombinant enzyme at $40^{\circ} \mathrm{C}$ for $6 \mathrm{~h}$. The final product was precipitated by adding five volumes of $95 \%$ ethanol. Negative-ion electrospray ionization mass spectrometry (ESI-MS) was performed on a Q-TOF mass spectrometer (Waters, Milford, MA, United States) to analyze the oligosaccharides. The sample was dissolved in acetonitrile/water $(1: 1, \mathrm{v} / \mathrm{v})$ and $5 \mu \mathrm{L}$ of the solution containing the dissolved sample was injected for analysis with $1 \mathrm{mM}$ ammonium bicarbonate /acetonitrile $(1: 1, \mathrm{v} / \mathrm{v})$ as the mobile phase at a flow rate of $10 \mu \mathrm{L} / \mathrm{min}$.

\section{Statistical Analysis}

The results of fermentation optimization and enzymatic characterization experiments were analyzed by the standard deviation method, using SPSS 18.0 (IBM, New York, NY, United States). All original data represented three biological replicates. The data presented in tables are expressed as means \pm standard deviations.

\section{RESULTS}

\section{Gene Cloning and Recombinant Strain Screening}

The gene encoding the full-length $\kappa$-carrageenase, $c g k Z$ is 1638 bp in length, whereas the genes encoding the truncated $c g k Z \Delta P s t$ and $c g k Z \triangle C B M$ are 1200 and 948-bp in length, respectively (Figure 1A). The results of agarose gel electrophoresis suggested that the target genes were well amplified from the genomic DNA of Zobellia sp. ZM-2 (Figure 1B). Based on the functional annotations of the $c g k Z$ gene in the NCBI Genbank database, the Pst was truncated in $c g k Z \Delta P s t$ and the CBM was truncated in $c g k Z \triangle C B M$, whereas their catalytic domains were retained. The expression vector pPIC9K used in this study contains $\alpha$-factor signal sequence that can promote the secretion of recombinant proteins. The recombinant vectors pPIC9K-cgkZ, pPIC9K-cgkZ $\triangle$ Pst and pPIC9K-cgkZ $\triangle C B M$ were transformed into $P$. pastoris after linearization. The gene encoding histidinol 
TABLE 2 | Copy numbers of target genes detected by real-time qPCR.

\begin{tabular}{lccc}
\hline Target gene & $\boldsymbol{C}_{\mathbf{t}}$ value (GAPDH) & $\boldsymbol{C}_{\mathbf{t}}$ value (target gene) & Copy number \\
\hline $\operatorname{cgk} Z$ & $14.26 \pm 0.17$ & $12.24 \pm 0.21$ & 7 \\
$c g k Z \Delta$ Pst & $14.67 \pm 0.12$ & $12.66 \pm 0.29$ & 7 \\
$\operatorname{cgk} Z \Delta C B M$ & $15.73 \pm 0.35$ & $14.14 \pm 0.41$ & 6 \\
\hline
\end{tabular}

$C_{t}$ values are "mean \pm standard deviation" from three replicates $(n=3)$.

dehydrogenase (HIS4) provides a selectable marker to isolate recombinant strains from $\mathrm{MD}$ plates, and the kanamycin resistance gene allows the selection of high activity colonies from YPD agar plates containing $4 \mathrm{mg} / \mathrm{mL}$ of G418 (Figure 1C). These strains were preserved for an analysis of gene copy number and the results are shown in Table 2 . The qPCR results showed a linear relationship between the gene copy number and $C_{t}$ value. The slope and $R^{2}$ of the amplification standard curve for cgkZ were -3.082 and 0.995 , respectively, while those for the endogenous control gene were -2.794 and 0.991 , respectively. Based on the standard curve, the copy numbers of gene $c g k Z$, $c g k Z \triangle P s t$, and $c g k Z \triangle C B M$ were approximately 7,7 and 6 , respectively.

\section{Optimization and Fermentation of Recombinant $\kappa$-Carrageenase}

In this study, the enzymatic activities of the recombinant extracellular enzymes were evaluated at four different temperatures (Figure 2A). The three recombinant enzymes exhibited high levels of activity below $24^{\circ} \mathrm{C}$. When the fermentation temperature reached $28^{\circ} \mathrm{C}$, the relative enzymatic activities decreased to $52-60 \%$, indicating that high fermentation temperatures inhibit the secretion of recombinant enzymes. The effect of $\mathrm{pH}$ on recombinant enzymatic activity is shown in Figure 2B. The results show that the optimum fermentation $\mathrm{pH}$ for enzymatic activity was 6-7, which was favorable for the production of the recombinant enzymes. When the fermentation $\mathrm{pH}$ was 5, the relative enzymatic activity decreased to approximately $73 \%$. The effect of methanol concentration on enzymatic activity is shown in Figure 2C. At methanol concentrations of $0.5-1 \%(\mathrm{v} / \mathrm{v})$, large amounts of the recombinant enzymes were secreted extracellularly, and they showed high activity levels. At the methanol concentration of $1.5 \%(\mathrm{v} / \mathrm{v})$, the relative enzymatic activity decreased to $82-86 \%$.

The curve for recombinant enzyme activity is shown in Figure 2D. Recombinant strains were cultured in a 1 -L shaker flask at $22^{\circ} \mathrm{C}, \mathrm{pH} 6$, and $1 \%(\mathrm{v} / \mathrm{v})$ methanol. From 0 to $24 \mathrm{~h}$, methanol was not added and no enzymatic activity was detected. With the first addition of methanol $(24 \mathrm{~h})$, methanol was used as the sole carbon source by the recombinant strains and $\kappa$-carrageenase secretion was observed. The maximum activity of the recombinant enzymes was detected at $96 \mathrm{~h}$ of incubation. The maximum activities for the recombinant enzymes cgkZ, $\operatorname{cgkZ} \Delta$ Pst, and $\operatorname{cgkZ} \triangle \mathrm{CBM}$ were $4.68,5.70$, and $3.02 \mathrm{U} / \mathrm{mL}$, respectively.

The results for gene transcription levels as measured by qPCR are shown in Table 3. The transcription levels of cgkZ, cgkZ $\Delta$ Pst, and $c g k Z \triangle C B M$ were significantly higher at $36 \mathrm{~h}$ than at $72 \mathrm{~h}$.
Compared with the transcription level of $c g k Z$, the transcription levels of $c g k Z \triangle P s t$ and $c g k Z \triangle C B M$ increased to 2.9- and 3.5-fold at $36 \mathrm{~h}$, and to 4.3 - and 2.8 -fold at $72 \mathrm{~h}$, respectively. Since the gene copy numbers of $c g k Z$ and $c g k Z \Delta P s t$ were similar, the higher enzymatic activity of cgkZ $\Delta$ Pst was due to its higher transcription level. This result indicated that truncation of the Pst increased the expression of the recombinant enzyme. However, the enzymatic activity of cgkZ $\triangle C B M$ was depressed even though $c g k Z \triangle C B M$ showed a higher transcription level than $c g k Z$, indicating that the truncation of the CBM may decrease the enzymatic activity of $\kappa$-carrageenase.

\section{Purification of Recombinant $\kappa$-Carrageenase}

The supernatants obtained from cultures grown under shaker-flask fermentation were concentrated before cation exchange chromatography. As shown in Table 4, after cation exchange chromatography, the specific activity of cgkZ increased by 9.7 -fold to $356.74 \mathrm{U} / \mathrm{mg}$, while the specific activities of cgkZ $\Delta$ Pst and cgkZ $\triangle C B M$ were 487.78 and $265.66 \mathrm{U} / \mathrm{mg}$, representing 10.4 - and 11.0 -fold increases, respectively. The SDS-PAGE result of the purified recombinant $\kappa$-carrageenase is shown in Figure 3. The molecular weights of $c g k Z, \operatorname{cgkZ} \Delta$ Pst and cgkZ $\triangle C B M$ were found to be approximately 65,45 , and $40 \mathrm{kDa}$, respectively. The molecular weights of these proteins significantly differed and most of the impurities were removed after cation exchange chromatography.

\section{Enzymatic Characterization of Recombinant $\kappa$-Carrageenase}

In this study, the temperature and $\mathrm{pH}$ ranges selected for optimization experiments were chosen based on the enzymatic characterization of $\kappa$-carrageenase produced by Zobellia sp. ZM2 , which had an optimum temperature and $\mathrm{pH}$ of $39^{\circ} \mathrm{C}$ and 6.0, respectively (Liu et al., 2013). The effect of temperature on recombinant $\kappa$-carrageenase activity expressed in $P$. pastoris is shown in Figure 4A. The recombinant enzyme cgkZ showed the highest activity at $50^{\circ} \mathrm{C}$ and its relative activity decreased to $89 \%$ at $55^{\circ} \mathrm{C}$. The recombinant enzymes cgkZ $\Delta$ Pst and cgkZ $\Delta \mathrm{CBM}$ showed the highest activities at $55^{\circ} \mathrm{C}$ and their relative activities decreased to 84 and $88 \%$ at $60^{\circ} \mathrm{C}$, respectively.

In the experiment for the determination of the enzymes' thermal stabilities, after incubation at $45^{\circ} \mathrm{C}$ for $4 \mathrm{~h}$, approximately $50 \%$ of the enzymatic activity was retained (Figure 4B). When the recombinant enzymes were incubated at $42.5^{\circ} \mathrm{C}$ for $4 \mathrm{~h}$, more than $90 \%$ of the enzymatic activity was retained (data not shown). All the recombinant enzymes were stable below $42.5^{\circ} \mathrm{C}$. Approximately $50 \%$ of the enzymatic activity was lost after $1 \mathrm{~h}$ of incubation at $47.5^{\circ} \mathrm{C}$ and after $30 \mathrm{~min}$ of incubation at $50^{\circ} \mathrm{C}$ (data not shown). These results demonstrate that these recombinant enzymes expressed by $P$. pastoris have a higher thermal stability than one that was previously expressed by E. coli, which was stable below $35^{\circ} \mathrm{C}$ (Liu et al., 2013). $\kappa$-Carrageenase obtained from Pseudoalteromonas porphyrae showed thermal stability at $30^{\circ} \mathrm{C}$ (Liu et al., 2011), which was also lower than the thermal stabilities of the recombinant enzymes expressed in this study. 

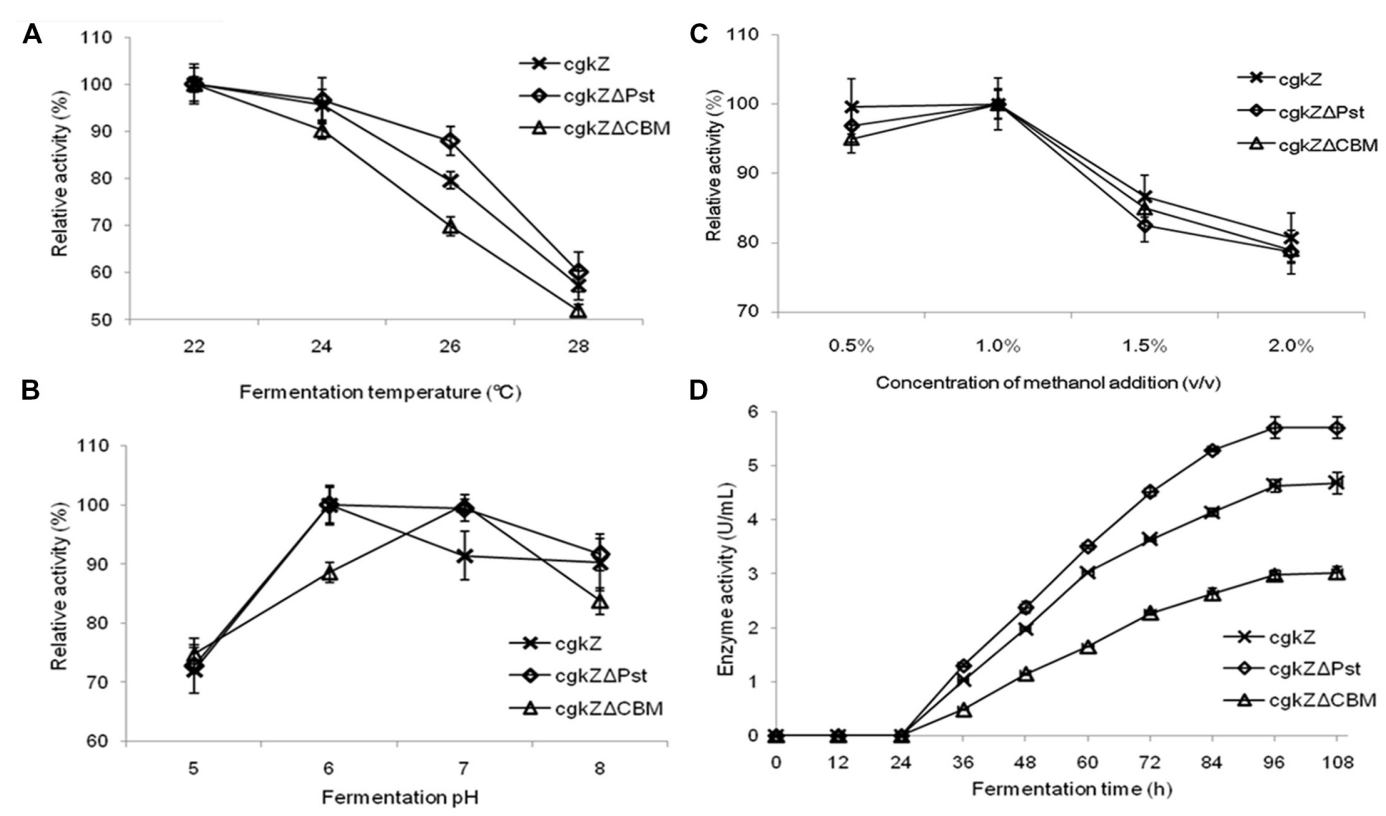

FIGURE 2 | Optimization of recombinant $\kappa$-carrageenase fermentation conditions. (A) The effect of fermentation temperature on enzymatic activity. (B) The effect of fermentation $\mathrm{pH}$ on enzymatic activity. (C) The effect of methanol addition concentration on enzymatic activity. (D) The curve of enzymatic activity of shake flask fermentation. Error bars represent the standard deviation, $n=3$.

TABLE 3 | Determination of transcription levels by real-time qPCR.

\begin{tabular}{|c|c|c|c|}
\hline cDNA & $C_{t}$ value (GAPDH) & $\boldsymbol{C}_{\mathrm{t}}$ value (target gene) & Transcript levels (related to GAPDH) \\
\hline $\operatorname{cgk} Z(36 \mathrm{~h})$ & $15.39 \pm 0.18$ & $12.47 \pm 0.49$ & 14.39 \\
\hline $\operatorname{cgk} Z \Delta P s t(36 \mathrm{~h})$ & $16.21 \pm 0.42$ & $11.97 \pm 0.36$ & 41.02 \\
\hline $\operatorname{cgk} Z \triangle C B M(36 \mathrm{~h})$ & $16.38 \pm 0.52$ & $11.64 \pm 0.61$ & 50.39 \\
\hline $\operatorname{cgk} Z(72 \mathrm{~h})$ & $17.22 \pm 0.58$ & $15.32 \pm 0.50$ & 7.73 \\
\hline $\operatorname{cgk} Z \Delta P s t(72 \mathrm{~h})$ & $18.63 \pm 0.31$ & $14.89 \pm 0.36$ & 33.96 \\
\hline $\operatorname{cgk} Z \triangle C B M(72 \mathrm{~h})$ & $16.20 \pm 0.07$ & $12.82 \pm 0.42$ & 21.58 \\
\hline
\end{tabular}

$C_{t}$ values are "mean \pm standard deviation" from three replicates $(n=3)$.

TABLE 4 | Purification and productivity of recombinant $\kappa$-carrageenase.

\begin{tabular}{|c|c|c|c|c|c|c|}
\hline Name & & Activity (U/mL) & Protein $(\mu \mathrm{g} / \mathrm{mL})$ & Specific activity (U/mg) & Activity recovery (\%) & Purification (-fold) \\
\hline \multirow[t]{2}{*}{$\operatorname{cgk} Z$} & Crude enzyme & 4.68 & 127.14 & 36.82 & 100 & 1 \\
\hline & CM-Sepharose & 5.95 & 16.68 & 356.74 & 35.9 & 9.7 \\
\hline \multirow[t]{2}{*}{$\operatorname{cgk} Z \Delta$ Pst } & Crude enzyme & 5.70 & 122.06 & 46.73 & 100 & 1 \\
\hline & CM-Sepharose & 6.71 & 13.75 & 487.78 & 34.2 & 10.4 \\
\hline \multirow[t]{2}{*}{$\operatorname{cgk} Z \Delta \mathrm{CBM}$} & Crude enzyme & 3.02 & 125.45 & 24.08 & 100 & 1 \\
\hline & CM-Sepharose & 4.39 & 16.52 & 265.66 & 34.0 & 11.0 \\
\hline
\end{tabular}

The effect of $\mathrm{pH}$ on recombinant $\kappa$-carrageenase activity is shown in Figure 4C. The recombinant enzyme cgkZ showed the highest activity at $\mathrm{pH} 7$ and its optimum $\mathrm{pH}$ was 6-7. The recombinant enzymes cgkZ $\Delta$ Pst and cgkZ $\Delta$ CBM showed the highest activities at $\mathrm{pH}$ 6.0, with an optimum $\mathrm{pH}$ of 5-7. For recombinant enzyme cgkZ, at $\mathrm{pH} 4$ or 8 , the relative activity decreased to approximately $76 \%$, indicating that it began to become inactivated under those conditions.
The effects of ions and chemical reagents on recombinant $\kappa$-carrageenase activity are shown in Table 5 . The results show that $\mathrm{Na}^{+}$promoted the activity of recombinant $\kappa$-carrageenase, while a high concentration of $\mathrm{K}^{+}$inhibited enzymatic activity. $\mathrm{Mg}^{2+}$ and $\mathrm{Ca}^{2+}$ stimulated the enzymatic activity slightly, while $\mathrm{Cu}^{2+}, \mathrm{Zn}^{2+}, \mathrm{Fe}^{2+}$, and $\mathrm{Fe}^{3+}$ strongly inhibited the activity. Among the tested chemical reagents, the addition of DTT stimulated enzymatic activity to $178-217 \%$, which was similar to the reports of Yao et al. (2012) and 


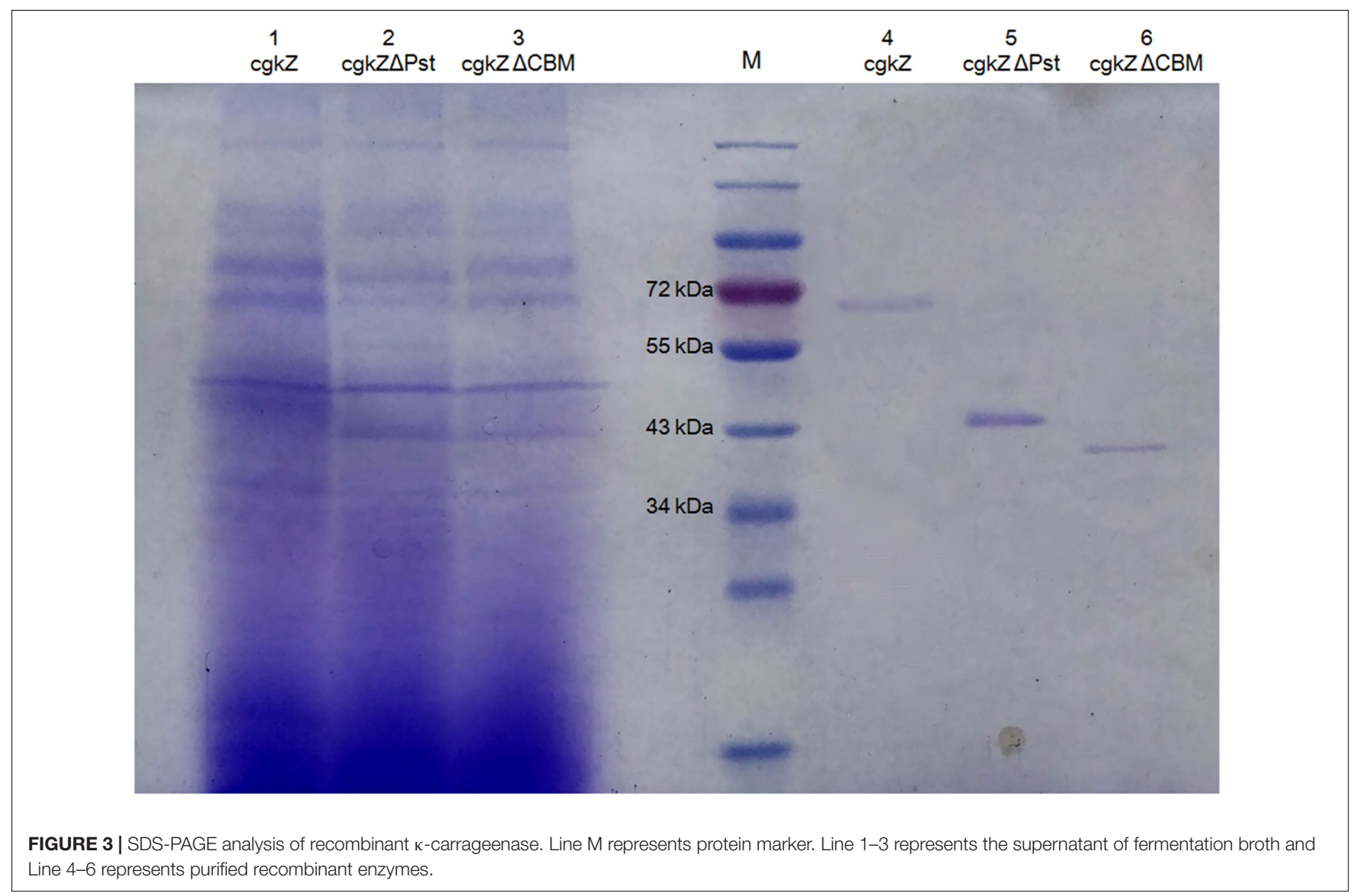

Liu et al. (2013). SDS significantly inhibited the enzymes. EDTA had slight inhibitory effects on the recombinant enzymes. TritonX-100, Tween-80, methanol, and glycerol had minimal effects on the activities of the three recombinant enzymes.

Based on the Lineweaver-Burk double reciprocal plots, the $\mathrm{K}_{\mathrm{m}}$ values of $\mathrm{cgkZ}, \mathrm{cgkZ} \Delta$ Pst and $\mathrm{cgkZ} \Delta \mathrm{CBM}$ were $2.07,1.85$, and $1.04 \mathrm{mg} / \mathrm{mL}$, respectively, which were higher than that reported by Liu et al. (2013) $(0.84 \mathrm{mg} / \mathrm{mL})$. Compared with the $\kappa$-carrageenase obtained from $P$. porphyrae $\left(\mathrm{K}_{\mathrm{m}} 4.4 \mathrm{mg} / \mathrm{mL}\right)$, these recombinant enzymes showed higher substrate affinities (Liu et al., 2011). The $\mathrm{V}_{\max }$ values of these recombinant enzymes were $0.77,1.35$, and $0.50 \mathrm{mg} / \mathrm{mL} \cdot \mathrm{min}$, respectively.

\section{Analysis of Recombinant Enzymatic Hydrolysis Products}

Although the recombinant enzymes were encoded by target genes with different lengths, the end-products after the enzymatic hydrolysis of $\kappa$-carrageenan were nearly the same. The MS spectrum is shown in Figure 5. Two intense fragment peaks were observed. An ion at $m / z 394(z=2)$ with a molecular weight of 790 Da represented a tetrasaccharide with two $\left[A-G_{4 S}\right]$ repeating units $\left(\left[\mathrm{A}-\mathrm{G}_{4 \mathrm{~S}}\right]_{2}\right)$. Another ion at $m / z 391(z=3)$ with a molecular weight of $1176 \mathrm{Da}$ represented a hexasaccharide with three $\left[A-G_{4 S}\right]$ repeating units ([A-G $\left.G_{4 S}\right]_{3}$ ) (Yu et al., 2017).
Some other weak peaks were also observed. The results of MS showed that the final products of enzymes cgkZ, cgkZ $\Delta$ Pst and cgkZ $\triangle \mathrm{CBM}$-catalyzed hydrolysis were mainly composed of $\kappa$-carrageenan tetrasaccharide and hexasaccharide, which is similar to the results obtained by Liu et al. (2013). Although the Pst and CBM were truncated in cgkZ $\Delta$ Pst and cgkZ $\triangle \mathrm{CBM}$, respectively, the catalytic properties of these enzymes did not change compared with those of the full-length recombinant enzyme.

\section{DISCUSSION}

The full-length $c g k Z$ and its truncated gene $(c g k Z \Delta P s t$, $c g k Z \triangle C B M)$ were expressed in $P$. pastoris. The extracellular enzymatic activities are 4.68, 5.70, and $3.02 \mathrm{U} / \mathrm{mL}$, respectively. The difference in their molecular weights $(65,45$, and $40 \mathrm{kDa}$, respectively) demonstrates the success of gene truncation. The three recombinant enzymes showed some common characteristics. Firstly, their enzymatic activities increased to $178-217 \%$ in the presence of the reducing agent DTT, and some metal ions $\left(\mathrm{Cu}^{2+}, \mathrm{Zn}^{2+}\right.$, and $\left.\mathrm{Fe}^{3+}\right)$ strongly inhibited their activities. Recombinant cgkZ has four cysteines (Cys), among which Cys137 is located in the active site of $\kappa$-carrageenase (Liu et al., 2013). It was reported that heavy metal ions have strong affinities for sulphydryl (-SH) residues, therefore, the presence 
A

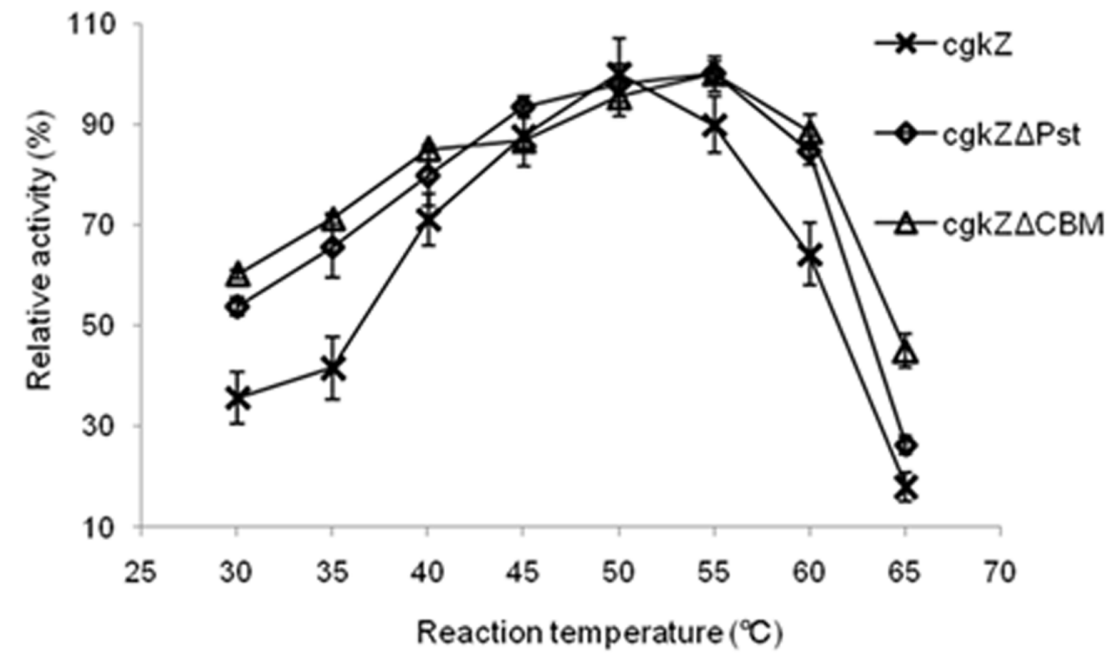

B
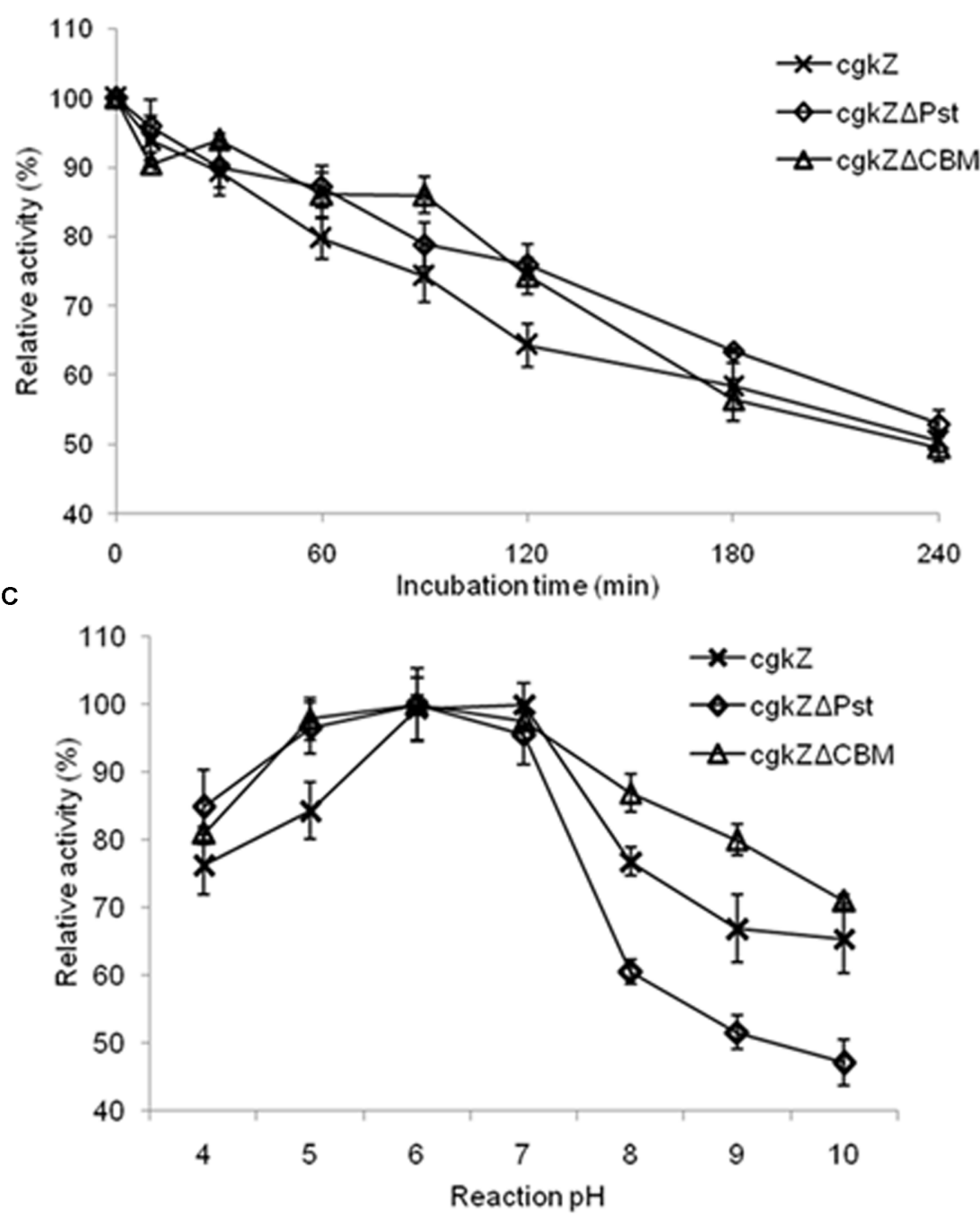

FIGURE 4 | Characterization of recombinant $\kappa$-carrageenase. (A) The effect of temperature on enzyme activity. (B) The thermostability of recombinant $\kappa$-carrageenase. The incubation temperature is $45^{\circ} \mathrm{C}$. (C) The effect of $\mathrm{pH}$ on enzyme activity. Error bars represent the standard deviation, $n=3$. 
TABLE 5 | Effects of ions and chemical reagents on the activity of recombinant $\kappa$-carrageenase.

\begin{tabular}{|c|c|c|c|c|}
\hline lons and chemical reagents & Concentrations & Relative activity of cgkZ (\%) & Relative activity of cgkZ $\Delta$ Pst (\%) & Relative activity of $\operatorname{cgkZ} \Delta \mathrm{CBM}(\%)$ \\
\hline $\mathrm{Na}^{+}$ & $10 \mathrm{mM}$ & $107.8 \pm 3.75$ & $108.0 \pm 5.25$ & $97.0 \pm 1.51$ \\
\hline $\mathrm{Na}^{+}$ & $50 \mathrm{mM}$ & $117.3 \pm 1.28$ & $123.7 \pm 1.35$ & $122.8 \pm 1.23$ \\
\hline $\mathrm{K}^{+}$ & $10 \mathrm{mM}$ & $118.5 \pm 4.21$ & $109.8 \pm 1.98$ & $101.2 \pm 0.38$ \\
\hline $\mathrm{K}^{+}$ & $50 \mathrm{mM}$ & $49.4 \pm 1.78$ & $68.6 \pm 2.31$ & $98.3 \pm 1.22$ \\
\hline $\mathrm{K}^{+}$ & $100 \mathrm{mM}$ & $34.6 \pm 1.86$ & $38.1 \pm 1.85$ & $10.6 \pm 0.15$ \\
\hline $\mathrm{Zn}^{2+}$ & $5 \mathrm{mM}$ & $28.0 \pm 0.59$ & $54.6 \pm 4.20$ & $58.4 \pm 0.89$ \\
\hline $\mathrm{Mg}^{2+}$ & $5 \mathrm{mM}$ & $104.3 \pm 0.91$ & $110.7 \pm 1.86$ & $106.9 \pm 1.84$ \\
\hline $\mathrm{Fe}^{2+}$ & $5 \mathrm{mM}$ & $68.2 \pm 2.53$ & $76.7 \pm 1.55$ & $79.5 \pm 1.34$ \\
\hline $\mathrm{Fe}^{3+}$ & $5 \mathrm{mM}$ & $24.7 \pm 2.40$ & $35.9 \pm 3.35$ & $31.0 \pm 0.55$ \\
\hline DTT & $5 \mathrm{mM}$ & $177.8 \pm 2.68$ & $216.8 \pm 8.61$ & $193.6 \pm 2.25$ \\
\hline Tween-80 & $0.5 \%(v / v)$ & $106.7 \pm 0.31$ & $101.6 \pm 2.27$ & $101.4 \pm 0.54$ \\
\hline Methanol & $0.5 \%(v / v)$ & $101.2 \pm 2.31$ & $108.6 \pm 5.51$ & $105.3 \pm 2.68$ \\
\hline Glycerol & $0.5 \%(v / v)$ & $103.2 \pm 0.87$ & $102.6 \pm 4.45$ & $102.9 \pm 1.15$ \\
\hline
\end{tabular}

Values are "mean \pm standard deviation" from three replicates $(n=3)$.

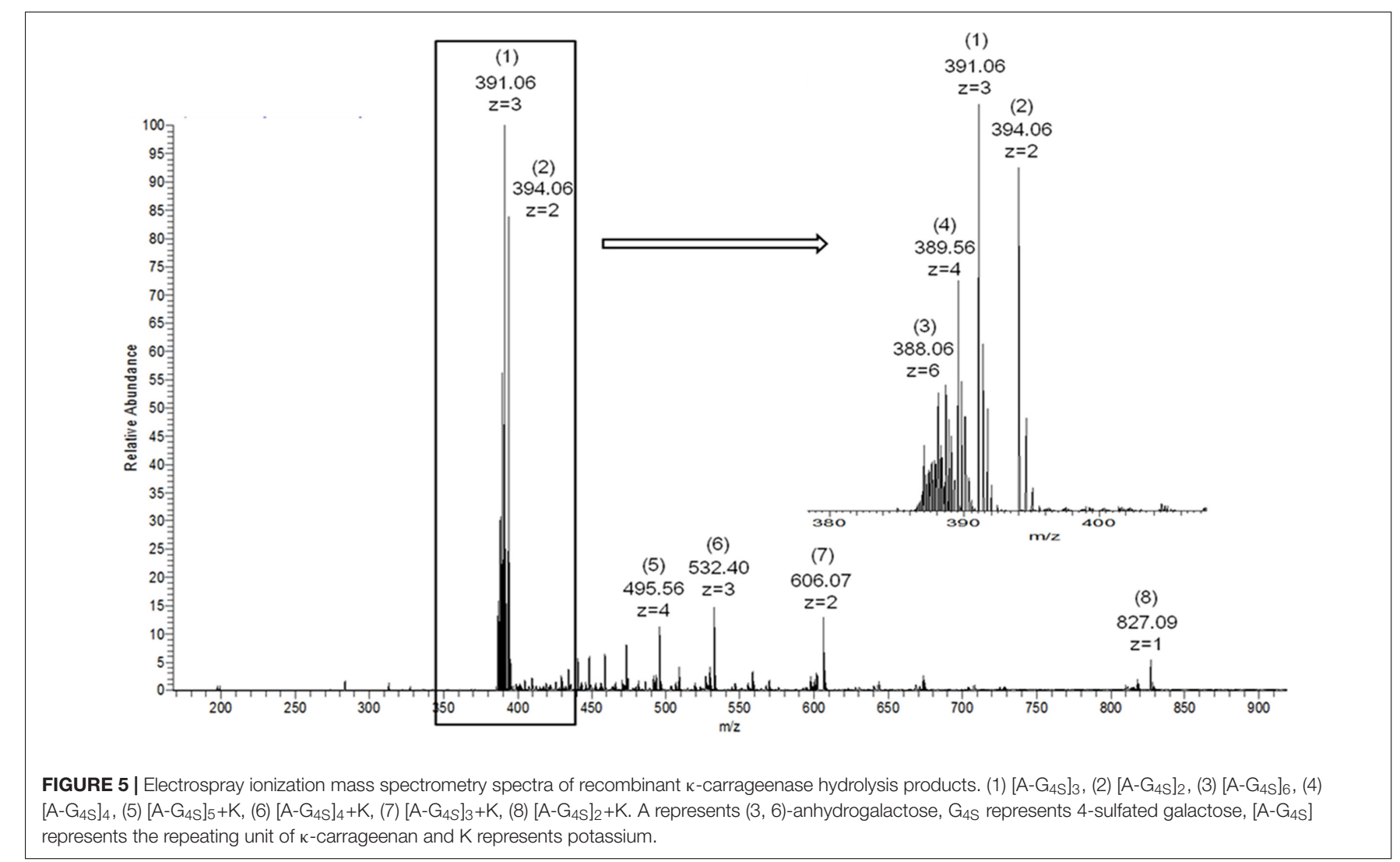

of heavy metal ions results in the negative conformational changes of recombinant enzymes (Yao et al., 2012; Liu et al., 2013). DTT can prohibit the formation of disulfide bonds and maintaining the regular conformational folding of enzyme. The catalytic Cys should be maintained in an active state under the protection of DTT (Zhu et al., 2011; Yao et al., 2012). Therefore, DTT is used as an enzymatic stimulation reagent in some cases. 
Secondly, all these recombinant enzymes showed optimal temperature exceeding $45^{\circ} \mathrm{C}$, and more than $60 \%$ of their activities were retained after $3 \mathrm{~h}$ of incubation at $45^{\circ} \mathrm{C}$. For comparison, the optimum temperature of cgkZ expressed in E. coli was $39^{\circ} \mathrm{C}$ (Liu et al., 2013). The thermal stability of $\kappa$-carrageenase expressed in $P$. pastoris was at least $5^{\circ} \mathrm{C}$ higher than those of the same protein expressed in $E$. coli. It was previously reported that $N$-glycosylation can significantly improve the thermal stability of recombinant enzymes expressed using P. pastoris (Guo et al., 2008; Han et al., 2014; Zhao et al., 2015). N-Glycosylation generates hydrogen bond networks surrounding the recombinant enzymes and enhances their conformational stability (Zou et al., 2013; Zhao et al., 2015). N-Glycosylation also significantly decreases dynamic fluctuations in the molecule structure of enzymes, which helps to improve their thermal stabilities (Yang et al., 2016). In proteins expressed using $P$. pastoris, $N$-glycosylation is mainly found in recombinant proteins containing the Asn-X-Ser/Thr sequence. In the present study, analyses using the NetNGlyc 1.0 server database ${ }^{2}$ revealed Asn70 and Asn255 as potential $\mathrm{N}$-glycosylation sites in recombinant $\kappa$-carrageenase. It was reported that in $P$. pastoris expressed proteins, the $N$-glycosylation occupied $21 \%$ (recombinant neutral protease I) and $30 \%$ (recombinant lipase A) of the total molecular weight, respectively (Lei et al., 2013; Vici et al., 2015). The molecular weight of cgkZ expressed in $P$. pastoris was approximately $65 \mathrm{kDa}$, which was higher than that of the same protein expressed in E. coli (45 kDa, Liu et al., 2013). These results suggest that $N$-glycosylation may have been present in the recombinant enzymes and thus promotes the increase of thermal stabilities.

Thirdly, the hydrolysis products obtained by catalysis mediated by recombinant cgkZ expressed in $P$. pastoris and E. coli were similar and were mainly composed of $\kappa$-carrageenan tetrasaccharide and hexasaccharide. The conserved sequence of the catalytic domain did not change after the truncation of the Pst and CBM of $\kappa$-carrageenase. Thus, the enzymatic properties and catalytic products remained unchanged.

The three recombinant enzymes showed significant differences in their enzymatic activities and gene transcription levels. $\kappa$-Carrageenase belongs to glycoside hydrolase family 16 (GH-16). From the description of the full-length $\kappa$-carrageenase sequence in the NCBI GenBank database ${ }^{3}$, the CBM is located behind the catalytic domain, while the Pst is located at the C-terminal. The Pst was usually found at the C-terminal of proteins from gram-negative strains such as Zobellia sp. and Porphyromonas sp., and it promotes the secretion of proteins (Sato, 2011; Saiki and Konishi, 2012, 2014). The secretion vector pPIC9K used in $P$. pastoris expression system contains sequence encoding the $\alpha$-factor signal peptide. Thus, the recombinant enzymes were secreted extracellularly and could be obtained by centrifugation. Therefore, the C-terminal Por secretion tail of the $\kappa$-carrageenase gene is not necessary in $P$. pastoris

${ }^{2}$ http://www.cbs.dtu.dk/services/NetNGlyc/

${ }^{3}$ https://blast.ncbi.nlm.nih.gov/Blast.cgi expression systems. It was reported that the truncation of several C-terminal amino acids from a recombinant xylanase belonging to the GH-10 family did not significantly affect its structure and function. Compared with the full-length xylanase, the specific activity of the truncated variant was improved by approximately 1.3-fold (Zheng et al., 2016). The target genes cgkZ and $c g k Z \Delta$ Pst had the same copy numbers. It was reported that gene copy number and heterologous protein expression had a linear correlation (Parashar and Satyanarayana, 2017). From the results of shaker-flask fermentation and purification, cgkZ $\Delta$ Pst showed a 1.2-fold higher enzymatic activity and 1.4-fold higher specific activity than cgkZ. Meanwhile, the transcription levels of $c g k Z \Delta P s t$ were also improved compared with that of $c g k Z$. These results showed that the Pst-truncated enzyme had a higher activity owing to a higher transcription level. None of negative effects on enzymatic properties were detected after Pst truncation.

The CBM of $\kappa$-carrageenase has a $\beta$-sandwich fold structure with a single carbohydrate binding site on the surface of the enzyme (Ribeiro et al., 2010). Although the CBM is a non-catalytic module which is independent from the catalytic domain, its function of substrate targeting contributes to the improvement of the enzymatic activity and substrate affinity (Grondin et al., 2014; Verma et al., 2015; Mompeán et al., 2017). The modification or removal of the CBM may significantly reduce the hydrolytic activity toward insoluble substrates and can sometimes affect the enzymatic activity toward soluble substrates (Mizutani et al., 2014; Kim et al., 2016). For instance, the truncation of the CBM 22 domain of xylanase decreased its relative activity toward insoluble xylan to $75 \%$, and the substrate affinity decreased to $80 \%$ in comparison with the full-length xylanase (Mollerup et al., 2016; Sermsathanaswadi et al., 2017). The enzymatic activity and specific activities of cgkZ $\triangle \mathrm{CBM}$ were 68 and $74 \%$ lower than those of $\mathrm{cgkZ}$, respectively. Although the CBM truncated enzyme showed a higher transcription level than the full-length cgkZ, its enzymatic activity significantly decreased owing to a lowered efficiency of substrate binding. It is predicted that the CBM has an important role in maintaining the enzymatic activity of $\kappa$-carrageenase.

\section{CONCLUSION}

The full-length and truncated recombinant $\kappa$-carrageenase enzymes expressed in $P$. pastoris showed superior thermal stabilities compared with the same enzymes expressed in E. coli. The Pst-truncated enzyme showed a higher transcription level and enzymatic activity than the full-length enzyme. The CBM-truncated enzyme showed a significant loss of enzymatic activity. The three recombinant enzymes possessed similar enzymatic properties. The application of the P. pastoris expression system combined with rational gene modification may be useful for preparing recombinant enzymes with high activities. This approach also provides a theoretical basis for the preparation of other marine glycoside hydrolase enzymes. 


\section{AUTHOR CONTRIBUTIONS}

YY performed all the experiments, coordinated the data analysis, and prepared this manuscript. ZL contributed in the experiment skills education. HM and LL contributed in the experimental proposal and manuscript polishing. MY, MC, ZW, and LS provided part of research work suggestion, prepared part of research materials and supervised this study.

\section{REFERENCES}

Cereghino, J. L., and Cregg, J. M. (2000). Heterologlous protein expression in the methylotrophic yeast Pichia pastoris. FEMS Microbiol. Rev. 24, 45-66. doi: 10.1111/j.1574-6976.2000.tb00532.x

Grondin, J. M., Chitayat, S., Ficko-Blean, E., Houliston, S., Arrowsmith, C. H., Boraston, A. B., et al. (2014). An unusual mode of galactose recognition by a family 32 carbohydrate-binding module. J. Mol. Biol. 426, 869-880. doi: 10.1016/j.jmb.2013.11.029

Guo, M., Hang, H., Zhu, T., Zhuang, Y., Chu, J., and Zhang, S. (2008). Effect of glycosylation on biochemical characterization of recombinant phytase expressed in Pichia pastoris. Enzyme Microb. Technol. 42, 340-345. doi: 10.1016/ j.enzmictec.2007.10.013

Han, M., Wang, X., Yan, G., Wang, W., Tao, Y., Liu, X., et al. (2014). Modification of recombinant elastase expressed in Pichia pastoris by introduction of N-glycosylation sites. J. Biotechnol. 171, 3-7. doi: 10.1016/j.jbiotec.2013. 11.021

Haon, M., Grisel, S., Navarro, D., Gruet, A., Berrin, J. G., and Bignon, C. (2015). Recombinant protein production facility for fungal biomass-degrading enzymes using the yeast Pichia pastoris. Front. Microbiol. 6:1002. doi: 10.3389/ fmicb.2015.01002

Hargreaves, P. I., Barcelos, C. A., da Augusto Costa, A. C., and Pereira, J. N. (2013). Production of ethanol 3G from Kappaphycus alvarezii: evaluation of different process strategies. Bioresour. Technol. 134, 257-263. doi: 10.1016/j.biortech. 2013.02.002

Kim, D. R., Lim, H. K., Lee, K. I., and Hwang, I. T. (2016). Identification of a novel cellulose-binding domain within the endo- $\beta-1,4$-xylanase KRICT PX-3 from Paenibacillus terrae HPL-003. Enzyme Microb. Technol. 9, 166-173. doi: 10.1016/j.enzmictec.2016.07.014

Lei, D., Xu, Y., He, Q., Pan, Y., Chen, B., Xiong, L., et al. (2013). Glycosylation analysis of recombinant neutral protease I from Aspergillus oryzae expressed in Pichia pastoris. Biotechnol. Lett. 35, 2121-2127. doi: 10.1007/s10529-0131314-3

Liu, G. L., Li, Y., Chi, Z., and Chi, Z. M. (2011). Purification and characterization of $\kappa$-carrageenase from the marine bacterium Pseudoalteromonas porphyrae for hydrolysis of $\kappa$-carrageenan. Process Biochem. 46, 265-271. doi: 10.1016/j. procbio.2010.08.021

Liu, Z., Li, G., Mo, Z., and Mou, H. (2013). Molecular cloning, characterization, and heterologous expression of a new $\mathrm{\kappa}$-carrageenase gene from marine bacterium Zobellia sp. ZM-2. Appl. Microbiol. Biotechnol. 97, 10057-10067. doi: 10.1007/ s00253-013-5215-0

Macauley-Patrick, S., Fazenda, M. L., Neil, B. M., and Harvey, L. M. (2005) Heterologous protein production using the Pichia pastoris expression system. Yeast 22, 249-270. doi: 10.1002/yea.1208

Michel, G., Chantalat, L., Duee, E., Barbeyron, T., Henrissat, B., Kloareg, B., et al. (2001). The $\kappa$-carrageenase of $P$. carrageenovora features, a tunnel-shaped active site: a novel insight in the evolution of Clan-B glycoside hydrolases. Structure 9, 513-525. doi: 10.1016/S0969-2126(01) 00612-8

Mizutani, K., Sakka, M., Kimura, T., and Sakka, K. (2014). Essential role of a family32 carbohydrate-binding module in substrate recognition by Clostridium thermocellum mannanase CtMan5A. FEBS Lett. 58, 1726-1730. doi: 10.1016/ j.febslet.2014.03.022

Mollerup, F., Parikka, K., Vuong, T. V., Tenkanen, M., and Master, E. (2016). Influence of a family 29 carbohydrate binding module on the activity of galactose oxidase from Fusarium graminearum. Biochim. Biophys. Acta 1860, 354-362. doi: 10.1016/j.bbagen.2015.10.023

\section{ACKNOWLEDGMENTS}

The authors would like to acknowledge the financial support from Public Science and Technology Research Funds Projects of Ocean (201505022), Shandong Science and Technology Development Project (2014GHY115037) and Fundamental Research Funds for the Central Universities (201762034).

Mompeán, M., Villalba, M., Bruix, M., and Zamora-Carreras, H. (2017). Insights into protein-carbohydrate recognition: a novel binding mechanism for CBM family 43. J. Mol. Graph. Model. 73, 152-156. doi: 10.1016/j.jmgm.2017.02.007

Mora-Gutierrez, A., Kumosinski, T. F., and Farrell, H. M. (1998). к-Carrageenan interaction with bovine and caprine caseins as shown by sedimentation and nuclear magnetic resonance spectroscopic techniques. J. Agric. Food Chem. 46, 4987-4996. doi: 10.1021/jf980387d

Mou, H. J., Jiang, X. L., and Guan, H. S. (2003). A к-carrageenan derived oligosaccharide prepared by enzymatic degradation containing anti-tumor activity. J. Appl. Phycol. 15, 297-303. doi: 10.1023/A:1025103530534

Parashar, D., and Satyanarayana, T. (2017). Production of chimeric acidic $\alpha$-amylase by the recombinant Pichia pastoris and its applications. Front. Microbiol. 8:493. doi: 10.3389/fmicb.2017.00493

Raman, M., and Doble, M. (2015). к-Carrageenan from marine red algae, Kappaphycus alvarezii- A functional food to prevent colon carcinogenesis. J. Funct. Foods 15, 354-364. doi: 10.1016/j.jff.2015.03.037

Ribeiro, T., Santos-Silva, T., Alves, V. D., Dias, F. M. V., Luís, A. S., Prates J. A. M., et al. (2010). Family 42 carbohydrate-binding modules display multiple arabinoxylan-binding interfaces presenting different ligand affinities. Biochim. Biophys. Acta 1804, 2054-2062. doi: 10.1016/j.bbapap.2010.07.006

Saiki, K., and Konishi, K. (2012). Strategies for targeting the gingipain secretion system of Porphyromonas gingivalis. J. Oral Biosci. 54, 155-159. doi: 10.1016/j. job.2012.03.003

Saiki, K., and Konishi, K. (2014). Assembly and function of PG27/LptO, PG0026, and HagA in the secretion and modification system of C-terminal domain proteins. J. Oral Biosci. 56, 115-119. doi: 10.1016/j.job.2014.07.001

Sato, K. (2011). Por secretion system of Porphyromonas gingivalis. J. Oral Biosci. 53, 187-196. doi: 10.1016/S1349-0079(11)80001-0

Sermsathanaswadi, J., Baramee, S., Tachaapaikoon, C., Pason, P., Ratanakhanokchai, K., and Kosugi, A. (2017). The family 22 carbohydrate-binding module of bifunctional xylanase/ $\beta$-glucanase Xyn10E from Paenibacillus curdlanolyticus B-6 has an important role in lignocellulose degradation. Enzyme Microb. Technol. 96, 75-84. doi: 10.1016/j.enzmictec.2016.09.015

Verma, A. K., Bule, P., Ribeiro, T., Brás, J. L. A., Mukherjee, J., and Gupta, M. N. (2015). The family 6 carbohydrate binding module (CtCBM6) of glucuronoxylanase ( $\mathrm{CtXynGH30)}$ of Clostridium thermocellum binds decorated and undecorated xylans through cleft A. Arch. Biochem. Biophys. 575, 8-21. doi: 10.1016/j.abb.2015.03.026

Vici, A. C., Cruz, A. F., Facchini, F. D. A., Carvalho, C. C., Pereira, M. G., Fonseca-Maldonado, R., et al. (2015). Beauveria bassiana lipase A expressed in Komagataella (Pichia) pastoris with potential for biodiesel catalysis. Front. Microbiol. 6:1083. doi: 10.3389/fmicb.2015.01083

Yang, H., Zhu, Q., Zhou, N., and Tian, Y. (2016). Optimized expression of prolyl aminopeptidase in Pichia pastoris and its characteristics after glycosylation. World J. Microbiol. Biotechnol. 32, 176. doi: 10.1007/s11274-016-2135-z

Yao, Z., Zhang, C., Lu, F., Bie, X., and Lu, Z. (2012). Gene cloning, expression, and characterization of a novel acetaldehyde dehydrogenase from Issatchenkia terricola strain XJ-2. Appl. Microbiol. Biotechnol. 5, 1999-2009. doi: 10.1007/ s00253-011-3541-7

Yu, Y., Yang, M., Yang, J., Su, Q., and Mou, H. (2017). Composition and characteristics of continuous enzymatic hydrolysis products from Kappaphycus striatum. J. Appl. Phycol. 29, 1647-1656. doi: 10.1007/s10811-017-1064-z

Zhang, Y., Yu, G., Li, B., Mu, X., Peng, H., and Wang, H. (2016). Hemicellulose isolation, characterization, and the production of xylo-oligosaccharides from the waste water of a viscose fiber mill. Carbohyd. Polym. 141, 238-243. doi: 10.1016/j.carbpol.2016.01.022 
Zhang, Y., Zhang, S., Xian, L., Tang, J., Zhu, J., Cui, L., et al. (2015). Expression and purification of recombinant human neuritin from Pichia pastoris and a partial analysis of its neurobiological activity in vitro. Appl. Microbiol. Biotechnol. 99, 8035-8043. doi: 10.1007/s00253-015-6649-3

Zhao, L., Geng, J., Guo, Y., Liao, X., Liu, X., Wu, R., et al. (2015). Expression of the Thermobifida fusca xylanase Xyn11A in Pichia pastoris and its characterization. BMC Biotechnol. 15:18. doi: 10.1186/s12896-015-0135-y

Zheng, F., Huang, J., Liu, X., Hu, H., Long, L., Chen, K., et al. (2016). N- and C-terminal truncations of a GH10 xylanase significantly increase its activity and thermostability but decrease its SDS resistance. Appl. Microbiol. Biotechnol. 100, 3555-3565. doi: 10.1007/s00253-015-7176-y

Zhu, C., Xu, Z., and Song, R. (2011). The endoglucanase from Bacillus subtilis BEC1 bears halo-tolerant, acidophilic and dithiothreitol-stimulated enzyme activity. World J. Microbiol. Biotechnol. 27, 2863-2871. doi: 10.1007/s11274-0110767-6

Zhu, Z. Y., Cui, D., Gao, H., Dong, F. Y., Liu, X., Liu, F., et al. (2016). Efficient synthesis and activity of beneficial intestinal flora of two lactulose-derived oligosaccharides. Eur. J. Med. Chem. 114, 8-13. doi: 10.1016/j.ejmech.2016. 03.007

Zou, S., Huang, S., Kaleem, I., and Li, C. (2013). N-glycosylation enhances functional and structural stability of recombinant $\beta$-glucuronidase expressed in Pichia pastoris. J. Biotechnol. 164, 75-81. doi: 10.1016/j.jbiotec.2012. 12.015

Conflict of Interest Statement: The authors declare that the research was conducted in the absence of any commercial or financial relationships that could be construed as a potential conflict of interest.

Copyright (c) 2017 Yu, Liu, Yang, Chen, Wei, Shi, Li and Mou. This is an open-access article distributed under the terms of the Creative Commons Attribution License (CC BY). The use, distribution or reproduction in other forums is permitted, provided the original author(s) or licensor are credited and that the original publication in this journal is cited, in accordance with accepted academic practice. No use, distribution or reproduction is permitted which does not comply with these terms. 